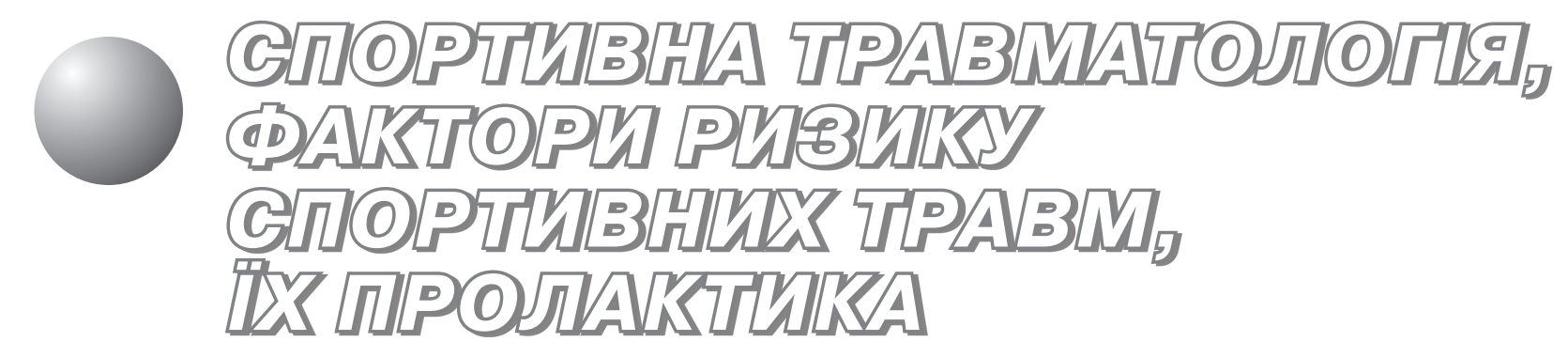

\title{
Особливості травматизму дзюдоїстів
}

\author{
УДК 796.853.23:616.8-009.1-085 \\ О. Б. Лазарєва, В. Є. Куропятник
}

Національний університет фізичного виховання і спорту України, Київ, Україна

\begin{abstract}
Резюме. Цель. Обобщить данные отечественных и зарубежных авторов по исследованиям травматизма в дзюдо и выявить наличие хронических поражений у дзюдоистов. Методы. Теоретический анализ и обобщение, систематизация, анализ научной и научнометодической литературы.

Результаты. Основой тренировочного и соревновательного процесса дзюдо являются броски, удержания, болевые и удушающие приемы, что приводит к достаточно высокому уровню травматизма. Первое ретроспективное исследование травматизма в дзюдо было проведено в Японии в 1943 г., после этого появилось более 20 фундаментальных исследований на эту тему. Во всех работах общий уровень травматизма был в среднем 88 травм на 1000 схваток для одного спортсмена. На верхние конечности приходится 50,1 \% травм, на нижние $-27,1 \%$, позвоночник - 10,7 \%, другие - 12,1\%. Травмы позвоночника встречаются относительно редко, но в дзюдо они имеют высокий риск повреждения спинного мозга. Занятия дзюдо повышают риск развития хронических заболеваний позвоночника: смещение межпозвоночных суставов, грыжа межпозвоночного диска, которые могут проявиться только по окончании спортивной карьеры.

Выводы. Необходимы ретроспективные и проспективные исследования хронических травм среди дзюдоистов с целью разработки эффективных мер их профилактики.

Ключевые слова: спорт, дзюдо, травматизм, ретроспективные исследования.
\end{abstract}

Abstract. Aim. Summarizing the data of domestic and foreign authors on the study of injuries in judo and detecting the presence of chronic lesions in judo.

Methods. Theoretical analysis and synthesis, classification, analysis of scientific and methodical literature.

Results. The basis of training and competitive process in judo are throws, retention, pain and chokes, which lead to a high enough level of injury. The first retrospective study of injuries in judo was held in Japan in 1943, then over 20 substantial researches on this topic were conducted. In all studies the overall injury rate constituted 88 injuries per 1,000 fights of an athlete on the average. In the upper limbs have $50,1 \%$ of injuries to the lower $-27,1 \%$ range $-10,7 \%$, other $-12,1 \%$. Spinal cord injuries are relatively rare, but in judo they have a high risk of spinal cord injury. Judo engagement increases the risk of chronic diseases of the spine: intervertebral joint displacement, herniated disc, which can occur only after termination of sporting career.

Conclusion. Therefore, retrospective and prospective studies of chronic injuries among judokas are required to develop effective measures of prevention.

Keywords: sports, judo, injuries, retrospective study.

Постановка проблеми. Дзюдо - олімпійський вид спорту, що бере свої витоки з японського національного єдиноборства, поєднуючи у собі жорстку боротьбу за перемогу і морально-етичні традиції східної цивілізації. Основою тренувального та змагального процесу є кидки, 
утримання, больові прийоми і задушливі прийоми, які застосовуються для подолання суперника у сутичці (відповідно до правил змагань). Спортсмени виступають без взуття в спеціальному одязі - куртці з поясом і брюках (дзюдока), на спеціальних матах - татамі. Під час боротьби стоячи за допомогою різних прийомів (підніжок, підсічок, кидків тощо) спортсмени прагнуть захопити дзюдоку супротивника (зручний для кидка захват) та провести кидок на татамі під час боротьби лежачи, застосовуючи захвати, утримати супротивника, притиснувши його спиною до татамі протягом 20 с або провести больовий прийом на руку чи техніку удушення, змусивши його визнати себе переможеним. Тривалість сутичок залежно від віку від 2 до 5 хв (без перерви). Від класичних видів боротьби (боротьба греко-римська та вільна) дзюдо відрізняється специфічним застосуванням фрізичних якостей при виконанні прийомів, що зумовлено великою різноманітністю дозволених технічних дій, в тому числі і наявністю одягу, за який можна брати захвати, а оцінювання йде лише за виконання кидків та зазначених вище прийомів. Саме ці особливості впливають на специфріку травмування.

Травматизм у дзюдо досліджувався на багатьох рівнях протягом всього існування виду спорту. У наукових працях за всі роки накопичилось багато різноманітних даних зі статистики й понятійних тлумачень. Останніми роками змінились тенденції тренувальної та змагальної діяльності, дзюдо як вид спорту став більш омолодженим. Згідно з останніми програмами спортивної підготовки дзюдоїстів набір до секцій розпочинається з чотирьох років, а статистичні дані участі учасників Олімпійських ігор [13], а також чемпіонатів та Кубків світу засвідчили зниження вікової групи на 5-8 років. Це змушує фахівців шукати проблему не лише у травматизмі, а й у розвитку хронічних порушень організму спортсменів.

Аналіз останніх досліджень і публікацій. Перше дослідження травматизму в дзюдо було проведено в Японії в 1943 р. [17]. Після цього з'явилося більше 20 досліджень на цю тему [8]. У всіх роботах загальний рівень травматизму був у межах 25,2-148 травм на 1000 сутичок для одного спортсмена (табл. 1). Такі межі можна пояснити різним трактуванням поняття «травма» - в одних випадках під травмою розумілося будь-яке пошкодження, синяк або подряпина, в інших роботах травмою вважалися випадки звернення за медичною допомогою. У найбільш великому і репрезентативному дослідженні A. Frey et al. (2004) наводяться дані Французької фредерації дзюдо про травми на змаганнях (за фрактом звернення в медслужбу змагань) за 9-річний період (з 1993 по 2002 р.), в яких взяли участь 150007 спортсменів і зафріксовано 17618 травм (13 травм на 1000 спортсменів на р.) [6]. Загальний рівень травматизму склав 44 пошкодження на 1000 сутичок. Подібний рівень травм отриманий і в інших недавніх дослідженнях - 42,6 і 41 [7, 11].

У порівняльному дослідженні фрінських вчених за 1995 р. показано, що рівень травматизму в дзюдо (117 травм на 1000 осіб на рік) значно перевищує такий у хокеї з шайбою (94), фрутболі (89), баскетболі (88) і волейболі (60), однак нижче рівня в карате (142) [15]. У дослідженні M. McPherson i W. Pickett [16] повідомляють про рівень травм у східних єдиноборствах, зафріксованому в приймальних відділеннях лікарень двох штатів Канади, зокрема дзюдо, посіло третє місце (99 травм ) після карате (299 травм) і таеквондо (129 травм). Дослідження Е. Е. Yard et al. [20], проведене в дитячих американських лікарнях, має схожий розподіл - 79,5 \% усіх травм, отриманих в східних єдиноборствах, доводиться на карате, 6,4 \% - на таеквондо, 4,8 \% - на дзюдо. В аналізі травм Національної університетської спортивної асоціації (NCAA) наводяться дані про рівень травм у 15 видах спорту, серед яких домінуюче місце належить американському фрутболу - 35, 9 травм на 1000 змагань, далі йдуть боротьба вільна - 26,4, фрутбол - 18,8, хокей з шайбою - 16,3, жіноча спортивна гімнастика - 15,2 [13]. Аналіз травм на літніх Олімпійських іграх 2008 в Пекіні показав, що серед єдиноборств рівень травм був наступним: таеквондо - 270 травм на 1000 спортсменів, бокс - 149, дзюдо - 112, боротьба - 94: найвищий рівень травматизму був у футболі - 315 травм на 1000 спортсменів [9].

В цілому на підставі розглянутих даних можна зробити висновок, що дзюдо досить травмонебезпечний вид спорту, що наближається за кількістю пошкоджень до таких ударних єдиноборств, як таеквондо і бокс, i випереджає боротьбу класичну і вільну, а також більшість

ТАБЛИЦЯ 1 - Рівні травматизму дзюдоїстів у декількох дослідженнях

\begin{tabular}{|l|c|c|}
\hline \multicolumn{1}{|c|}{ Дослідження } & $\begin{array}{c}\text { Кількість } \\
\text { досліджуваних }\end{array}$ & $\begin{array}{c}\text { Рівень } \\
\text { травматизму* }\end{array}$ \\
\hline D. Barrault et al. (1983) [1] & 16496 & 122 \\
\hline J. S. Phillips et al. (2001) [18] & 210 & 148 \\
\hline G. James \& W. Pieter (2003) [11] & 126 & 43 \\
\hline A. Frey et al. (2004) [6] & 150007 & 44 \\
\hline C. M. Green et al. (2007) [7] & 392 & 41 \\
\hline
\end{tabular}

* Кількість травм на 1000 сутичок на змаганні. 
ігрових видів спорту, спортивну гімнастику та інші неконтактні види спорту.

Виділення невирішених раніше частин загальної проблеми, котрим присвячується стаття. Враховуючи загальну травмонебезпечність в дзюдо під час тренувального процесу та змагань, логічним буде припустити розвиток хронічних захворювань на тлі відсутності корекційно-відновної системи та довголітнього здоров'язбереження дзюдоїстів.

Роботу виконано згідно зі Зведеним планом НДР у сорері фрізичної культури та спорту на 2011-2015 рр. за темою 4.4 «Удосконалення організаційних і методичних основ програмування процесу фрізичної реабілітації при дисфункціональних порушеннях у різних системах організму людини» (номер держреєстрації 0111U001737).

Мета дослідження - узагальнити дані вітчизняних й зарубіжних авторів стосовно досліджень травматизму в дзюдо та виявити наявність хронічних уражень у дзюдоїстів.

Методи дослідження: теоретичний аналіз і узагальнення, систематизація, аналіз наукової та науково-методичної літератури.

Результати дослідження та їх обговорення. Найбільш поширений тип травм у більшості досліджень - розтягнення м'язів і зв'язок (у середньому 30 \%), струси мозку (в середньому 24 \%), більшість з яких були легкими [8]. Серед тяжких травм найчастіше відбуваються переломи, вивихи, відкриті рани (розсічення) і черепномозкові травми [16, 20].

У роботі С. М. Green et al. (2007) повідомляється, що переважна більшість травм траплялися в стійці (83 \%), при цьому більшість з них відбувалися в боротьбі за захватом (28 \% загальної кількості травм), при виконанні кидка: у того,

ТАБЛИЦЯ 2 - Локалізація травм у спортсменів, які взяли участь у трьох змаганнях 3 дзюдо у Великій Британії, n = 53 [7].

\begin{tabular}{|l|c|}
\hline \multicolumn{1}{|c|}{ Локалізація } & $\%$ \\
\hline Голова & 18,9 \\
\hline Шия & 3,8 \\
\hline Лице & 7,5 \\
\hline Рот / зуби & 3,8 \\
\hline Ніс & 3,8 \\
\hline Верхня кінцівка & 41,5 \\
\hline Плече & 11,3 \\
\hline Лікоть & 9,4 \\
\hline Пальці & 20,8 \\
\hline Нижня кінцівка & 28,3 \\
\hline Коліно & 13,3 \\
\hline Надп'яткова гомілка & 7,5 \\
\hline Стопа / пальці стопи & 7,5 \\
\hline
\end{tabular}

хто виконує кидок (25\%), і у того, хто падає (23 \%) [7]. В іншому дослідженні повідомляється, що переважну більшість травм було отримано в результаті падіння, кидка або стрибка [16]. У кількох роботах аналізувалися травми, отримані на тренуваннях і змаганнях. Результати сильно різняться - в кількох дослідженнях показано, що на тренуваннях відбувається приблизно в два рази більше травм, ніж на змаганнях, в інших роботах розподіл приблизно однаковий.

Аналіз праць свідчить, що в цілому на верхні кінцівки дзюдоїстів доводиться більше травм, ніж на нижні. При цьому найчастіше підлягає ризику плечовий суглоб [8]. У дослідженні A. Frey et al. (2004) на верхні кінцівки доводилося 50,1\% травм, на нижні - 27,1 \%, хребет і спину $10,7 \%$, інші - 12,1 \% [6]. Розподіл, отриманий в дослідженнях Е. Е. Yard et al. (2007), представлений в таблиці 2.

У кількох дослідженнях зазначається, що переважна більшість пошкоджень має легкий характер. Однак у дослідженнях відсутнє обговорення питання симуляції травми та отримання медичної допомоги для короткочасного перепочинку й відновлення сил, яке є дуже важливим, оскільки частина легких травм зумовлена саме цією причиною. Травма вважається серйозною, якщо спортсмен не може завершити поєдинок або змушений пропустити тренувальні дні. У дослідженні A. Frey [6] з 44 пошкоджень на 1000 поєдинків лише 5,7 / 1000 були серйозними. У дослідженні G. James i W. Pieter (2003) рівень серйозних травм був 4,85 / 1000 і 13,7/ 1000 у чоловіків і жінок відповідно (загальний рівень 42,6 / 1000) [11]. У роботі C. M. Green et al. [7] лише 11,5 \% травмованих дзюдоїстів не змогли продовжити сутичку. При цьому наголошується, що 36,5 \% травмованих дзюдоїстів виграли сутичку, в якій отримали травму. У дослідженні M. McPherson i W. Pickett [16], які аналізували рівень травматизму за зверненнями до лікарні, рівень серйозних ушкоджень - вище $27 \%$.

3 цієї проблеми існує багато протиріч. У дослідженні C. М. Green аналізувалися такі фактори, як стать, рівень майстерності, вагова категорія і не було виявлено будь-яких кореляцій за цими параметрами. Однак було виявлено, що ті спортсмени, які різко скидали вагу більш ніж на $5 \%$ були більше схильні до травм, ніж ті, хто цього не робив [7]. У кількох дослідженнях показано, що жінки отримують більше травм, ніж чоловіки [12, 19]. В іншому дослідженні тих же авторів показано, що чоловіки отримують більше травм, ніж жінки, проте у жінок був більше відсоток важких травм $[11,19]$. При аналізі травм коліна в дзюдо 
було показано, що у жінок було більше травм передньої хрестоподібної зв'язки, проте відмінності статистично не значимі [12]. Можливо це сталося через недостатньо велику вибірку, тому що для дуже багатьох видів спорту показано, що жінки частіше пошкоджують передню хрестоподібну зв'язку, ніж чоловіки.

R. G. Owens i E. J. Ghadiali [8] повідомили про ознаки аноксичного пошкодження головного мозку у досвідчених дзюдоїстів і припустили, що це пов'язано з частими задушливими прийомами. Тим не менш, було вивчено гострі та хронічні наслідки задушливих прийомів за допомогою електроенцефралограми i досліджень регіонального мозкового кровообігу в 10 конкурентних італійських дзюдоїстів і зроблено висновки, що немає свідчень, які вказують на ризик задушливих прийомів для центральної нервової системи [8].

У дзюдо біль у спині виникає в результаті повторних падінь, піднімань суперника за рахунок м'язів спини, розтягнень і скручувань. Біль у спині, як правило, лікується із застосуванням болезаспокійливих засобів відпочинку. Фізіотерапія і остеопатія також можуть принести певну користь. Пошкодження м'язів спини можуть відбутися як у того, хто кидає, так і у того, кого кидають. Різкий рух при виконанні прийому може бути особливо небезпечний і здатний призвести до розтягнень зв'язок і м'язів, і навіть до їх розриву.

Травми хребта зустрічаються відносно рідко, але в дзюдо постійний фрізичний контакт, повторні важкі приземлення і падіння можуть збільшити ризик пошкодження хребта. Травми хребта можуть бути потенційно небезпечні для життя, під ними маються на увазі ступінь пошкодження спинного мозку, який може, у легких випадках, тимчасово вплинути на відчуття і свідомість, більш серйозні травми можуть призвести до локалізованого або повного паралічу. Всі травми хребта повинні бути перевірені лікарем, проте такі симптоми, як втрата свідомості і реакції на стимули, оцінюються в першу чергу. Травми хребта в дзюдо зумовлені високою швидкістю удару об поверхню, ударами об суперника та перевантаженням м'язів у момент ротації хребта під час виконання кидків або запобіганню технічних дій супротивника. Неправильне приземлення після падіння може мати серйозні наслідки для хребта. Відновлення після травми хребта може зайняти багато часу, і деякі люди ніколи не зможуть відновитися повністю.

Серед загальних рекомендацій, що стосуються оволодіння правильною технікою виконання прийомів, страховки та самостраховки при падіннях і кидках, виконання повноцінної розминки, дотримання правил, належного стану інвентарю та обладнання залу для занять та інших загальновідомих заходів, слід зазначити фракт, показаний у роботі C. M. Green et al. [7]. Автори повідомляють, що виявили достовірну кореляцію між ризиком травмування і різким зниженням маси тіла перед змаганням - зниженням маси тіла більше ніж на $5 \%$ значно збільшує ризик ушкодження [7]. Нещодавно в дзюдо з позицій збереження здоров'я було переглянуто деякі положення правил проведення змагань [2]. У змаганнях юних дзюдоїстів (до 14 років) введено ряд обмежень: заборонено всі задушливі і больові прийоми та кидки з колін (через спину, «млин»). Для спортсменів віком до 12 років забороняється також виконувати кидки з попереднім падінням на спину або бік (через голову з упором стопи в живіт, підсід гомілкою), через груди прогином або обертом, передні, бічні, задні підніжки на п'яті сідаючи. А. А. Шахов та ін. [2] пропонують обмежити технічний арсенал юних дзюдоїстів i самбістів, виключивши з нього такі небезпечні для хребта прийоми, як кидок через спину, через груди з прогином, «млин», бічний і передній перевороти - ці прийоми слід вводити вже на пізніх етапах підготовки спортсменів [2].

Вже з 2015 р., у зв'язку з опрацюванням даних стосовно травматизму дзюдоїстів і стрімким зростанням кількості травм хребта у дітей та дорослих, було введено уточнення до правил змагань. Особливу увагу приділили падінням на «міст», прямим падінням та упором на голову, а також усім падінням із гіперекстензією хребта. Всі ці положення або уникнення падінь у цих положеннях вважаються за поразку [10].

3 огляду на це, дослідження, присвячені травматизму в дзюдо, проводяться регулярно і грунтовно. Також розробляються різноманітні методики відновлення, запобігання та профрілактики травмам, які, на думку сучасних дослідників, порушують тренувальний цикл борців та призводять до зниження їхньої змагальної результативності. Останнім часом достатню увагу почали приділяти психоемоційній складовій спортсменів єдиноборців та впливу специфріки діяльності на моральний стан та психічне здоров'я індивідуальності спортсмена, але це робиться також для покращення результативності змагальної діяльності, а не з гуманістичних поривів.

У дослідженнях фрахівці майже не торкаються питання здоров'я спортсменів, які вже закінчили свою спортивну кар'єру, хоча вони якраз і $€$ показниками впливу специфічної спортивної діяльності (виду спорту) на загальне здоров'я, показники якого різко знижуються з віком як у 
спортсменів, так і у тих, хто перестав активно займатися спортом або взагалі покинув його.

Серед хронічних захворювань $€$ деякі дані про поширеність остеоартриту суглобів пальців кисті у дзюдоїстів [8]. А. А. Шахов та ін. [2] припускають, що заняття дзюдо і самбо підвищують ризик розвитку хронічних захворювань хребта - зміщення міжхребцевого суглоба, грижа міжхребцевого диска, які можуть проявитися лише після закінчення спортивної кар'єри. Тому необхідні ретроспективні й проспективні дослідження хронічних травм серед дзюдоїстів 3 метою розробки ефективних заходів їх профрілактики. Слід продовжувати проспективно оцінювати рівень травм на змаганнях і тренуваннях з дзюдо серед дорослих і дітей, щоб дослідити фрактори ризику, такі, як вік, стать, рівень майстерності, попередні травми, зниження маси тіла перед змаганням тощо. Зміни в правилах дзюдо повинні вноситися з урахуванням епідеміологічних даних травматизму, а подальші дослідження повинні оцінювати ефективність унесених змін та інших профрілактичних заходів, наприклад, методу тейпування надп'ятково-гомілкового суглоба.

Тому постає питання запобігання негативних впливів спорту на організм спортсменів. Фіксується достатня кількість вертеброгенних порушень в осіб, які перестали активно займатися боротьбою дзюдо або стали тренерами чи суддями, незважаючи на незначний травматизм хребта. Однак ці порушення не належать до спортивного травматизму і фрахівці не шукають

\section{Література}

1. Траßмы в дзюдо. - [Электронный ресурс] // Peжим доступа: http://www.sportmedicine.ru/judo.php. 10.06.2012.

2. Шахов A. A. Здоровьесбережение занимающихся дзюдо и самбо на основе учета воздействий техники бросков на позвоночник / А. А. Шахов, В. В. Мелихов, О. С. Понарина // Учен. зап. ун-та имени П. Ф. Лесгафрта. -2010 . - № 2 (60). - С.128-131.

3. Японцы вычислили самый опасный вид спорта - это дзюдо. - [Электронный ресурс] // Режим доступа: http:// newsru.com/sport/21sep2011/do.html - 21.09.2011.

4. Barrault $D$. Accidents et incidents survenus au cours des de compŭtitions de judo [in French] / D. Barrault, B. Achou, R. Sorel // Symbioses. - 1983. - Vol. 15, N 3. - P. 144-152.

5. De Loës M. A 7-year study on risks and costs of knee injuries in male and female youth participants in 12 sports / M. de Loës, L. J. Dahlstedt, R. Thomée // Scand J Med Sci Sports. - 2000. - Vol. 10, N 2. - P. 90-97.

6. Frey $A$. Neuf saisons de surveillance mŭdicale de compŭtitions de judo [in French] / A. Frey, D. Rousseau, B. Vesselle et al. // J. de Traumatologie du Sport. - 2004. Vol. 21, N 2. - P. 100-109. шляхів вирішення, оскільки найчастіше цих людей не відносять до категорії спортсменів, статистика спортивного травматизму або його наслідків їх не враховує, а тому й немає пошуків засобів профрілактики цим негативним процесам.

Висновки. Травматизм для спортсменів завжди був і залишається важливою складовою тренувального і змагального процесів, що негативно впливають на результативність та морально «збивають» від досягнення можливостей, які напрацьовувались роками. Від травм цілком уберегтись неможливо, але це не стосується розвитку хронічної патології у спортсменів, з якою потрібно боротись.

Через специфріку своєї діяльності у дзюдоїстів латентно розвиваються вертеброгенні порушення, що супроводжуються проявом негативних симптомів, гострих синдромів і погіршують якість тренувальної і змагальної діяльності, а після завершення спортивної кар'єри проявляються більш виразно та небажано впливають вже на якість життя. Виходячи із даних тверджень, детальне вивчення цього питання, а також засоби і методи реабілітації та профрілактики потребують нагального вирішення.

Перспективи подальших досліджень. На базі теоретичних та емпіричних досліджень проявів вертеброгенних порушень у дзюдоїстів інструментально визначити найбільш уразливу зону та вікові межі найбільш активного розгортання і розробити відповідну програму превентивної фрізичної реабілітації, застосовуючи сучасні підходи на фоні особливостей виду спорту.

\section{References}

1. Injuries in judo. - [Electronic resource] // Access mode: http://www.sportmedicine.ru/judo.php. - 10.06.2012.

2. Shahov $A$. A. Preserving health of athletes engaged in judo and sambo on the basis of accounting for the impact of throwing technique upon spine / A. A. Shahov, V. V. Melihov, O. S. Ponarina // Uchenyie zapiski universiteta imeni P. F. Lesgafta. - 2010. - N 2 (60). - P. 128-131.

3. Japanese have determined the most dangerous sports event - judo. - [Electronic resource] // Access mode stupu: http://newsru.com/sport/21sep2011/do.html. 21.09.2011.

4. Barrault D. Accidents et incidents survenus au cours des de compŭtitions de judo [in French] / D. Barrault, B. Achou, R. Sorel // Symbioses. - 1983. - Vol. 15, N 3. - P. 144-152.

5. De Loës M. A 7-year study on risks and costs of knee injuries in male and female youth participants in 12 sports / M. de Loës, L. J. Dahlstedt, R. Thomée // Scand J Med Sci Sports. - 2000. - Vol. 10, N 2. - P. 90-97.

6 . Frey $A$. Neuf saisons de surveillance mŭdicale de compŭtitions de judo [in French] / A. Frey, D. Rousseau, B. Vesselle et al. // J. de Traumatologie du Sport. - 2004. Vol. 21, N 2. - P. 100-109. 
7. Green C. M. Injuries among judokas during competition. / C. M. Green, M. J. Petrou, M. L. Fogarty-Hover, C. G. Rolf // Scand J Med Sci Sports. - 2007. - Vol. 17, N 3. - P. 205-210.

8. Harmer P. A. Chapter 13: Judo in Epidemiology of injury in Olympic sports / P. A. Harmer, D. J. Caine, M. A. Schiff // Blackwell Publishing. - 2010. - 518 p.

9. Hootman J. M. Epidemiology of collegiate injuries for 15 sports: summary and recommendations for injury prevention initiatives / J. M. Hootman, R. Dick, J. Agel // J Athl Train. - 2007. - Vol. 42, N 2. - P. 311-319.

10. International Judo Federation. - [Електронний ресурс] // Режим доступу: http://www.ijf.org/ 31.01.2015

11. James $G$. Injury rates in adult elite judoka / G. James, W. Pieter // Biol Sport. - 2003. - Vol. 20, N 1. P. 25-32.

12. James $G$. Competition injuries in young judo athletes. / G. James, W. Pieter // 1st International Judo Federaton Conference. October 4-5. - Birmingham, 1999.

13. Junge $A$. Sports injuries during the Summer Olympic Games 2008 / A. Junge, L. Engebretsen, M. L. Mountjoyet al. // Am J Sports Med. - 2009. - Vol. 37. - N 11. - P. 21652172.

14. Kordi R. Combat sports medicine / R. Kordi et al. (eds.) Springer Science. 2009.

15. Kujala U. M. Acute injuries in soccer, ice hockey, volleyball, basketball, judo, and karate: analysis of national registry data / U. M. Kujala, S. Taimela, I. Antti-Poika et al. // BMJ. - 1995. - Vol. 311, N 7018. - P. 1465-1468.

16. McPherson M. Characteristics of martial art injuries in a defined Canadian population: a descriptive epidemiological study / M. McPherson, W. Pickett // BMC Public Health. 2010. - Vol. 10. - P. 795.

17. Nakata M. Statistical observation on injuries from judo [in Japanese] / M. Nakata, N. Shirata // Nippon Seikeigeka Gakkai Zasshi [Journal of the Japanese Orthopaedic Association]. - 1943. - Vol. 18. - P. 1146-1154.

18. Phillips J. S. Injury surveillance in taekwondo and judo during physiotherapy coverage of the Seventh All-Africa Games. / J. S. Phillips, J. M. Frantz, S. L. Amosun, W. Weitz // South African J. of Physiotherapy. - 2001. - Vol. 57, N 1. - P. 32-34.

19. Pieter $W$. Competition injuries in young and adult judo athletes. / W. Pieter, C. De Crée // The Second Annual Congress of the European College of Sport Science. August 20-23. - Copenhagen, 1997.

20. Yard E. E. Pediatric martial arts injuries presenting to Emergency Departments, United States 1990-2003 / E. E. Yard, C. L. Knox, G. A. Smith, R. D. Comstock // J Sci Med Sport. - 2007. - Vol. 10, N 4. - P. 219-226.

kuroyatnik@bk.ru

helenka_1@mail.ru
7. Green C. M. Injuries among judokas during competition. / C. M. Green, M. J. Petrou, M. L. Fogarty-Hover, C. G. Rolf // Scand J Med Sci Sports. -2007. - Vol. 17, N 3. - P. 205-210.

8. Harmer P. A. Chapter 13: Judo in Epidemiology of injury in Olympic sports / P. A. Harmer, D. J. Caine, M. A. Schiff // Blackwell Publishing. - 2010. - 518 p.

9. Hootman J. M. Epidemiology of collegiate injuries for 15 sports: summary and recommendations for injury prevention initiatives. / J. M. Hootman, R. Dick, J. Agel // J Athl Train. - 2007. - Vol. 42, N 2. - P. 311-319.

10. International Judo Federation. - [Електронний ресурс] // Режим доступу: http://www.ijf.org/ 31.01.2015.

11. James G. Injury rates in adult elite judoka / G. James, W. Pieter // Biol Sport. - 2003. - Vol. 20, N 1. P. 25-32.

12. James $G$. Competition injuries in young judo athletes. / G. James, W. Pieter // 1st International Judo Federaton Conference. October 4-5. - Birmingham, 1999.

13. Junge $A$. Sports injuries during the Summer Olympic Games 2008 / A. Junge, L. Engebretsen, M. L. Mountjoy et al. / / Am J Sports Med. - 2009. - Vol. 37. - N 11. - P. 21652172.

14. Kordi R. Combat sports medicine / R. Kordi et al. (eds.) Springer Science. - 2009.

15. Kujala U. M. Acute injuries in soccer, ice hockey, volleyball, basketball, judo, and karate: analysis of national registry data / U. M. Kujala, S. Taimela, I. Antti-Poika et al. // BMJ. - 1995. - Vol. 311, N 7018. - P. 1465-1468.

16. McPherson M. Characteristics of martial art injuries in a defined Canadian population: a descriptive epidemiological study / M. McPherson, W. Pickett / / BMC Public Health. 2010. - Vol. 10. - P. 795

17. Nakata M. Statistical observation on injuries from judo [in Japanese] / M. Nakata, N. Shirata // Nippon Seikeigeka Gakkai Zasshi [Journal of the Japanese Orthopaedic Association]. - 1943. - Vol. 18. - P. 1146-1154.

18. Phillips J. S. Injury surveillance in taekwondo and judo during physiotherapy coverage of the Seventh All-Africa Games. / J. S. Phillips, J. M. Frantz, S. L. Amosun, W. Weitz // South African J. of Physiotherapy. - 2001. - Vol. 57, N 1. - P. 32-34.

19. Pieter $W$. Competition injuries in young and adult judo athletes. / W. Pieter, C. De Crée // The Second Annual Congress of the European College of Sport Science. August 20-23. - Copenhagen, 1997.

20. Yard E. E. Pediatric martial arts injuries presenting to Emergency Departments, United States 1990-2003 / E. E. Yard, C. L. Knox, G. A. Smith, R. D. Comstock // J Sci Med Sport. - 2007. - Vol. 10, N 4. - P. 219-226.

Надійшла 10.02.2016 